\title{
Worldwide occurrence of virus-infections in filamentous marine brown algae
}

\author{
D. G. Müller \& B. Stache \\ Fakultät für Biologie der Universität; D-W-7750 Konstanz, Federal Republic of Germany
}

\begin{abstract}
Virus infections were detected in Ectocarpus siliculosus and Ectocarpus fasciculatus on the coasts of Ireland, California, Peru, southern South America, Australia and New Zealand; in three Feldmannia species on the coasts of Ireland, continental Chile and Archipelago Juan Fernandez (Chile); and in Leptonematella from Antarctica. Natural populations on the Irish coast contained $3 \%$ infected plants in E. fasciculatus, and less than $1 \%$ in Feldmannia simplex. On the Californian coast, 15 to $25 \%$ of Ectocarpus isolates were infected. Virus symptoms were absent in E. siliculosus from Peru, but appeared after meiosis in laboratory cultures. The virus particles in E. fasciculatus are identical in size and capsid structure to those reported for $E$. silliculosus, while the virus in $F$. simplex is smaller and has a different envelope. Our findings suggest that virus infections are a common and worldwide phenomenon in filamentous brown algae.
\end{abstract}

\section{INTRODUCTION}

While fungal parasites in marine brown algae are well known and systematically documented (Andrews, 1976), evidence for virus-infections has been encountered only sporadically in several EM studies. The few findings of "virus-like particles" to date were listed by Ushiyama (1985).

In 1988, a population of Ectocarpus siliculosus in New Zealand was found to be infected with a double-stranded DNA virus, which is expressed in abortive gametangia or sporangia (Müller et al., 1990). Culture experiments with this material demonstrated that the virus genome is closely associated with that of the host. New infections occur when the virus enters the unicellular motile spores or gametes. Recombination during meiosis on an infected host plant can produce healthy, symptom-free progeny (Müller, 1991a). The fact that virus-infected plants in the natural habitat and in culture may be vital and at least partly reproductive demonstrates that host and virus have acquired the potential to co-exist in a non-lethal and perhaps pandemic manner.

We present here observations on the geographic distribution and the presence of virus infections in field populations from various coasts of the world.

\section{MATERIALS AND METHODS}

Infection symptoms in Ectocarpus and related genera can be easily detected by light microscopy because they are expressed in abnormal reproductive structures. Samples of ectocarpoid algae collected in the field habitat were examined under the light micro- 
scope with $10 \times$ and $40 \times$ objectives. Specimens fixed and stained with carmine in $45 \%$ acetic acid were mounted in Karo syrup. The hyaline content of host cells containing virus particles was found to stain intensely with acetocarmine. Unialgal cultures of healthy and virus-infected plants were derived from filament fragments of field material. Culture medium (Provasoli-ES; Starr \& Zeikus, 1987) was renewed at one- or two-week intervals. Cultures were kept at $12 \pm 1{ }^{\circ} \mathrm{C}$ and illuminated with white fluorescent lamps at $10 \mu \mathrm{mol}$ $\mathrm{m}^{-2} \mathrm{~s}^{-1}$ for $14 \mathrm{~h}$ per day. For electron microscopy, cultured plants were fixed and embedded in Spurr's resin following techniques described previously (Müller et al., 1990).

\section{RESULTS}

\section{Ectocarpus fasciculatus Harvey from Ireland}

This species was found epiphytic on Scytosiphon lomentaria (Lyngb.) Link at Killeany Bay, Aran Islands, in September 1990. Among a total of 91 specimens examined, 2 plants showed virus symptoms; while some plurilocular zoidangia appeared normal, others showed a mosaic arrangement of healthy sections and virus-compartments (Fig. 1). Clonal cultures derived from these two plants maintained this mosaic character. Electron microscopy revealed virus particles in the hyaline sections of the zoidangia (Fig. 2). These particles have the same structural characteristics as those found in Ectocarpus siliculosus from New Zealand (Müller et al., 1990). They are polyhedral, 131-135 nm in diameter, and have a laminated envelope (Fig. 3).

\section{Ectocarpus fasciculatus Harvey from California}

Since no mature ectocarpoid plants were found at various locations of the Californian coast in October 1989, small inoculates of scrapings from Nereocystis luetkeana (Mert.) Post. \& Rupr. and Laminaria sp. originating from Carmel, California, were incubated. From the resulting raw cultures, 26 unialgal isolates of $E$. fasciculatus were obtained. Four of these showed virus symptoms (Fig. 4). As in the Irish material, the virus particles are polyhedral, with a diameter of $138-144 \mathrm{~nm}$ and with a laminated envelope (Figs 5,6 ). Four unialgal Ectocarpus isolates were made from a raw culture of Sphacelaria rigidula Kützing collected at Montana de Oro (Morro Bay). One culture developed virus symptoms with the same characteristics as the materials from Carmel, and a virus particle size of 131-141 nm (Figs 7-9). A single Ectocarpus plant isolated as an epiphyte from Egregia menziesii (Turn.) Aresch. collected at Davenport Landing (Santa Cruz) also showed virus symptoms.

\section{Ectocarpus fasciculatus Harvey from southern South America}

In February 1989, collections at the following locations contained E. fasciculatus specimens with virus symptoms in plurilocular zoidangia: Estancia Moat (Ushuaia, Argentina, Fig. 10), Cameron (Bahia Inutil, Tierra del Fuego, Chile, Fig. 11), and Puerto Deseado (Patagonia, Argentina, Fig. 12). The virus symptoms in all these isolates persisted in clonal cultures. 


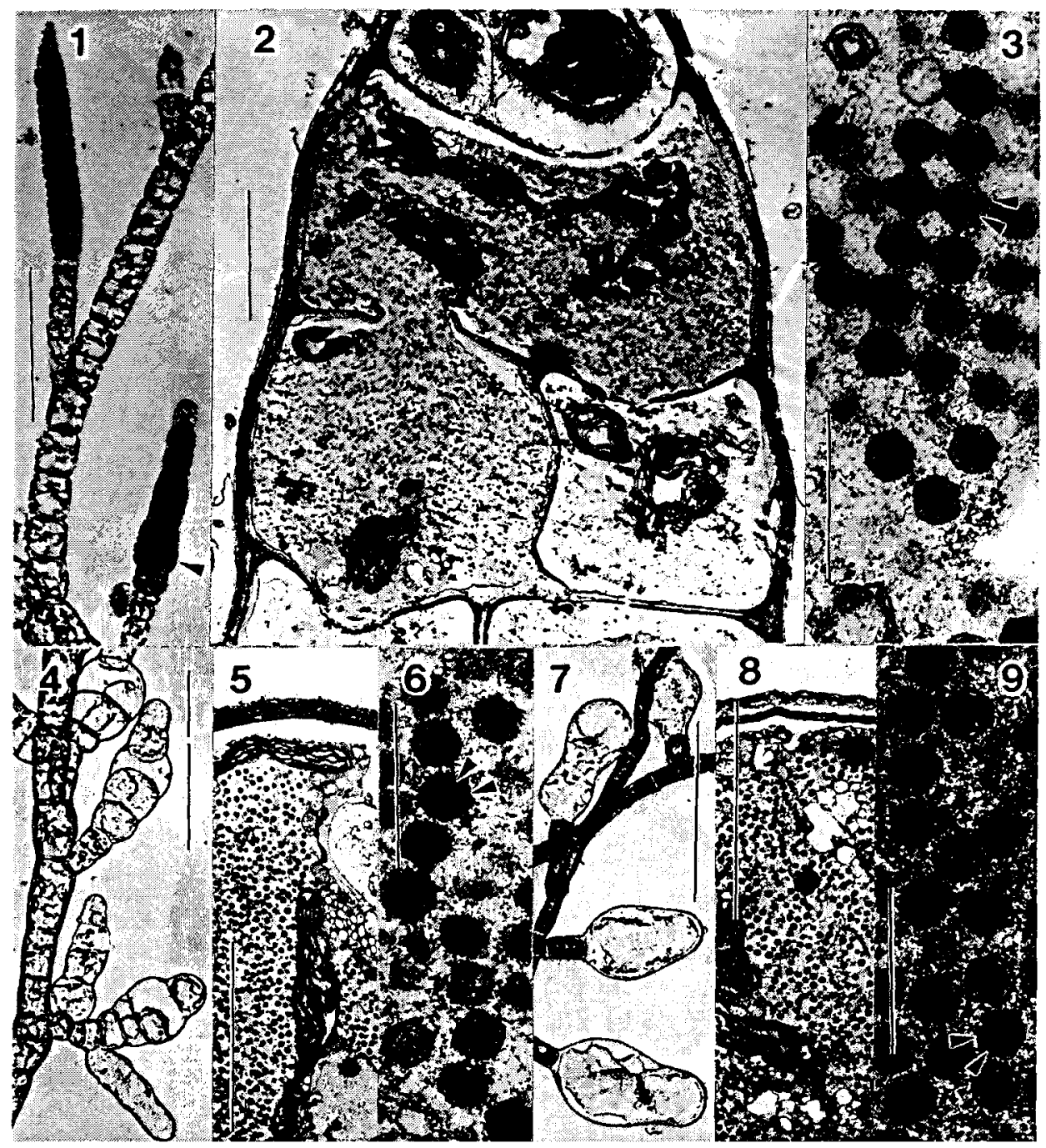

Figs 1-3. Ectocarpus fasciculatus from Ireland. Fig. 1: Permanent mount of a wild specimen with a normal (above) and a virus-producing plurilocular zoidangium with a normal section (below, arrow). Scale bar: $100 \mu \mathrm{m}$, applies to all light microscopic illustrations. Fig. 2: Longitudinal EM section through plurilocular zoidangium with virus formation. Scale bar: $5 \mu \mathrm{m}$. Fig. 3: Higher magnification showing polyhedric virus particles with laminated envelope (arrows, apply also to Figs 6 and 9). Scale bar: $0.5 \mu \mathrm{m}$

Figs 4-6. Unialgal culture of Ectocarpus fasciculatus from Carmel, California, with virus symptoms in plurilocular zoidangia in light microscopic appearance (Fig. 4) and EM sections (Fig. 5, scale bar: 5

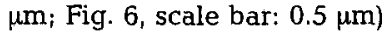

Figs 7-9. Unialgal culture of Ectocarpus fasciculatus from Morro Bay, California; light microscopic appearance (Fig. 7) and EM sections (Fig. 8, scale bar: $5 \mu \mathrm{m}$; Fig. 9, scale bar: $0.5 \mu \mathrm{m}$ ) 







\section{Ectocarpus siliculosus (Dillw.) Lyngb. from Australia}

Field material collected in the intertidal zone of Flinders, Victoria in September 1988 consisted predominantly of normal E. siliculosus gametophytes. However, in two specimens all plurilocular reproductive structures were diverted to virus formation (Fig. 13). Unialgal cultures maintained this character, but occasionally some functional gametangia were formed.

\section{Ectocarpus siliculosus (Dillw.) Lyngb. from Peru}

In a raw culture of Desmarestia peruviana Mont. collected in November 1988 at Bahia San Juan, Nazca, a healthy looking Ectocarpus sporophyte appeared. Meiospores from unilocular sporangia of this plant produced normal gametophytes and some plants with mosaic arrangements of normal and virus-forming sections in their plurilocular zoidangia (Fig. 14).

\section{Ectocarpus siliculosus (Dillw.) Lyngb. from Norway}

In October 1977, 43 gametophytes were collected at Bergen and used to establish unialgal cultures for a study on sexual compatibility (Müller, 1979). One male gametophyte showed symptoms of virus-infection, when re-activated from stock cultures in 1990. Inspection of a permanent slide made in April 1978 from the same isolate (Fig. 15) showed that virus symptoms were already present at this early stage of the culture.

\section{Feldmannia simplex (Crouan) Hamel from Ireland}

This species was found epiphytic on Codium fragile (Sur.) Hariot in the intertidal zones of Killeany Bay and Brannock Island (Aran Islands, Ireland) in September 1990. On one Codium plant, 270 Feldmannia specimens had normal plurilocular zoidangia, while 5

Figs 10-12. Ectocarpus fasciculatus. Unialgal cultures derived from plants collected in southern South America. Fig. 10: Ushuaia, Beagle Canal, Argentina; plant shows normal, virus-forming and mixed plurilocular zoidangia (arrow). Scale bar: $100 \mu \mathrm{m}$, applies to all light microscopic illustrations. Fig. 11: Cameron, Tierra del Fuego, Chile, normal and virus-producing plurilocular zoidangia on same plant. Fig. 12: Puerto Deseado, Argentina, plant with normal and virus-producing plurilocular zoidangium

Fig. 13. Ectocarpus siliculosus. Permanent mount of a virus-infected specimen collected in Flinders, Victoria, Australia in Sept. 1988

Fig. 14. Ectocarpus siliculosus from Peru. Virus-symptoms in plurilocular zoidangia of a plant derived from a unilocular sporangium in culture. Arrow: normal section

Fig. 15. Permanent mount of a male gametophyte of Ectocarpus siliculosus from Bergen, Norway, made in April 1978 shows one normal gametangium (n) and one with virus production (v)

Figs 16-19. Feldmannia simplex from Ireland. Fig. 16: Basal part of normal plant with functional pluri- $(p)$ and unilocular sporangia (u). Fig. 17: Basal part of virus-infected plant with hyaline vesicular structures containing virus particles. Fig. 18: Low magnification EM section through a vesicular compartment of an infected plant. The entire cellular content is converted to virus production, with few remnants of host cell organelles persisting. Scale bar: $5 \mu \mathrm{m}$. Fig. 19: Higher magnification: polyhedral virus particles in Feldmannia cell with a simple envelope Scale bar: 
plants showed virus symptoms. An additional 855 Feldmannia plants from 15 Codium hosts were all normal.

Clonal cultures were initiated from healthy and virus-infected Feldmannia plants. Healthy plants formed functional uni- and plurilocular sporangia (Fig. 16). Spores from both types of sporangia developed in an identical manner, without evidence of sexuality. In contrast, the virus-infected isolates were sterile. Virus particles were formed in clusters of hyaline vesicular cells. Their position on the base of erect filaments indicates that they correspond to modified zoidangia (Fig. 17). Virus-infected Feldmannia cultures can be propagated by fragmentation and regeneration of filaments. Occasionally, some of these regenerates appeared as healthy plants and had normal functional zoidangia.

Virus particles are liberated from the vesicles of infected Feldmannia plants in the same manner as described for Ectocarpus siliculosus (Müller, 1991b). When motile zoids of healthy Feldmannia plants were exposed to virus particles, 20 to $30 \%$ of the resulting daughter plants expressed virus symptoms. Electron microscopic examination of virusinfected Feldmannia plants revealed dense aggregates of virus particles and remnants of cell organelles within the hyaline vesicular structures (Fig. 18). The Feldmannia virus is a polyhedral particle, $112-130 \mathrm{~nm}$ in diameter. Its envelope seems to consist of a simple electron-dense layer (Fig. 19), in contrast to the Ectocarpus virus with a laminated envelope (Figs 3, 6, 9).

\section{Feldmannia globifer (Kuetz.) Hamel from oceanic Chile}

A specimen of Codium fernandezianum Setchell collected at Santa Clara Island, Archipelago Juan Fernandez in February 1991 was densely covered with ectocarpoid epiphytes. 12 plants of Feldmannia globifer from this sóurce were used to establish clonal cultures. Among these, 11 were normal and healthy, while one isolate showed hyaline vesicles similar to those described above for Feldmannia simplex. Virus symptoms persist in this culture in a cryptic manner, while many regenerates produced from filament fragments are fertile and appear to be completely healthy.

\section{Feldmannia irregularis (Kuetz.) Hamel from continental Chile}

An epiphyte on Scytothamnus australis (J. Ag.) Hooker \& Harvey collected in January 1984 near Puerto Montt, X. Region, gave rise to a clonal culture of $F$. irregularis. In addition to normal plurilocular zoidangia this culture showed conspicuous abnormalities, which persisted in culture and are now recognized as symptoms of virus infection.

\section{Leptonematella fasciculata (Reinke) Silva from Antarctica}

In January 1988, an abnormal specimen of $L$. fasciculata was collected at Bahia Fildes, King George Island, and preserved as a permanent slide. Examination of this material shows that apical portions of mature filaments consist of series of hyaline cells, the contents of which stain intensely with acetocarmine. Some cells with functional plurilocular zoidangia are interspersed in a mosaic manner, thus confirming the characteristic features of virus symptoms for Leptonematella. 


\section{DISCUSSION}

Virus infections in compact brown algal thalli can be expected to be difficult to identify, because symptoms seem to be restricted to reproductive stages of the host. Thus, the only known case to date is Chorda tomentosa Lyngb. (Laminariales), where viruslike particles have been detected in moribund meiospores (Toth \& Wilce, 1972). For this reason, we concentrated our search on filamentous brown algal taxa, which permit the detection of virus symptoms more easily.

The findings of virus infections in Ectocarpus siliculosus and Ectocarpus fasciculatus reported here reveal a surprisingly large and possibly global range, including Atlantic and Pacific oceans with subarctic, temperate and subantarctic coasts.

Various comments and illustrations in floristic literature indicate that, in the past, virus-infected algae have been encountered without knowledge of the correct diagnosis. Cardinal (1964) recorded the occurrence of Ectocarpus dimorphus Silva for the English Channel area, and cites older reports from Pacific North America, Algeria, northern France and Greenland. The illustrations and their interpretation by Cardinal indicate convincingly that this taxon represents virus-infected specimens of Ectocarpus. Similar findings were reported by Ardré (1969) for the coast of Portugal, and by Jaasund (1965) for northern Norway.

Culture experiments with clonal isolates of E. siliculosus and Feldmannia simplex show that the virus infection induces a stable transformation of the host plants. In the case of the Norwegian isolate of $E$. siliculosus described above, the virus is still present after 14 years in culture. This fits with genetical studies in New Zealand isolates of E. siliculosus which indicate that the virus genome associates closely with the genome of the host. It passes through mitosis and meiosis in a highly coordinated manner (Müller, 1991a).

Virus-infected Ectocarpus plants in field collections and laboratory cultures are often seen with mosaic-structured plurilocular zoidangia. These produce functional zoids which are able, at least partially, to restore and maintain normal development of the host. This feature is subject to great variability. In extreme cases, plants like the Peruvian $E$. siliculosus can be found that appear completely healthy. The existence of its virus infection became apparent only after meiosis under culture conditions. An extrapolation of this tendency suggests that Ectocarpus plants can be found which rarely or never express their virus infection..

Likewise, cultures of Feldmannia simplex and Feldmannia globifer produce regenerates that cannot be distinguished from normal, healthy plants. It remains an open question as to whether, in these cases, the virus genome has been eliminated or effectively suppressed. It seems possible that the entire Feldmannia population of a given natural habitat has been in contact with the virus genome in the past. Virus-specific molecular markers applied to a large number of individual plants will be necessary to evaluate this assumption. Additional biochemical studies and infection experiments are needed to evaluate the specificity of host-virus interactions in the genera Feldmannia and Ectocarpus.

Nucleic acid composition and genome size of the $F$. simplex virus is still unknown. Although there are many similarities with the Ectocarpus system, the differences in envelope structure suggest that the two viruses are distinct entities.

Ectocarpus and Feldmannia are placed in the order Ectocarpales. The finding of 
virus symptoms in field specimens of Leptonematella, which belongs to the order Chordariales, suggests that virus infections may be a general feature in the entire class Phaeophyceae.

Reanney (1974) proposed an important role of viruses in eukaryote evolution as vectors for non-sexual gene transfer. This hypothesis requires a well-balanced coexistence between DNA-viruses and their hosts, as well as pandemic or at least widespread occurrence. Both prerequisites are fulfilled in Ectocarpus and possibly also in Feldmannia. Biochemical studies on the molecular genetics, and biological experiments on the specificity of these systems will be necessary to determine if, and to what extent, viruses can act as vectors for horizontal gene transfer in Ectocarpus and Feldmannia.

Acknowledgements. Parts of this study were supported by the Deutsche Forschungsgemeinschaft. The Chilean institutions INACH and CONAF provided access and logistic support for field work in Antarctica and Juan Fernandez Archipelago. Thanks are due to Dr. R. Westermeier, for organizing a phycological expedition to subantarctic South America, and to Dr. A. Peters for collecting material from Peru. Our work in Ireland was done aboard the German RV "Heincke" (Helgoland).

\section{LITERATURE CITED}

Andrews, J. H., 1976. The pathology of marine algae. - Biol. Rev, 51, 211-253.

Ardré, F., 1969. Contribution à l'étude des algues marines du Portugal. I. La Flore. - Acta Biol. 10, 137-555.

Cardinal, A., 1964. Etude sur les Ectocarpacées de la Manche. - Nova Hedwigia (Beih.) 15, 1-86.

Jaasund, E., 1965. Aspects of the marine algal vegetation of North Norway. - Botanica gothoburg. 4, $1-174$.

Müller, D. G., 1979. Genetic affinity of Ectocarpus siliculosus (Dillw.) Lyngb. from the Mediterranean, North America and Australia. - Phycologia 18, 312 $<318$.

Müller, D. G., 1991a. Mendelian segregation of a virus genome during host meiosis in the marine brown alga Ectocarpus siliculosus. - J. Pl. Physiol. 137, 739-743.

Müller, D. G., 1991b. Marine virioplankton produced by infected Ectocarpus siliculosus (Phaeophyceae). - Mar. Ecol. Prog. Ser. 76, 101-102.

Müller, D. G., Kawai, H., Stache, B. \& Lanka, S., 1990. A virus infection in the marine brown alga Ectocarpus siliculosus (Phaeophyceae). - Botanica Acta 103, 72--82.

Reanney, D. C., 1974. Viruses and evolution. - Int. Rev. Cytol. 37, 21-52.

Starr, R. C. \& Zeikus, J. A., 1987. UTEX - The culture collection of algae at the University of Texas at Austin. - J. Phycol. 23 (Suppl.), 1-47.

Toth, R. \& Wilce, R. T., 1972. Viruslike particles in the marine alga Chorda tomentosa Lyngbye (Phaeophyceae) - J. Phycol. 8, 126-130.

Ushiyama, R., 1985. Viruses in fungi and eukaryotic algae: Their possible origins and evolution. Microbiol. Sci. 2, 181-184. 